\title{
Phytochemical and Biological Investigation of Aloe Grandidentata Salm- Dyck
}

\author{
Taghreed A Ibrahim ${ }^{1,3 *}$, Nabaweya M EL Fiki ${ }^{1}$, Ibrahim A Shehata ${ }^{1,2}$, Amany A Sleem ${ }^{4}$ and Mouchira M Shoukry ${ }^{1}$ \\ ${ }^{1}$ Pharmacognosy Department, Faculty of Pharmacy, Cairo University, Egypt \\ ${ }^{2}$ Pharmacognosy Department, Faculty of Pharmacy, King Abd El Aziz University, Saudi Arabia \\ ${ }^{3}$ Pharmacognosy Department, Faculty of Pharmacy, King Saud University, Saudi Arabia \\ ${ }^{4}$ Pharmacology Department, National Research Center, Dokki, Giza, Egypt
}

\begin{abstract}
The crude alcoholic extract of the leaves of Aloe grandidentata Salm.-Deck showed significant antimicrobial activity $(200 \mathrm{mg} / \mathrm{ml})$, potent anti-inflammatory and chronic antihyperglycemic (100 mg/kg b.wt.) compared to standard positive drugs. Phytochemical studies of the potent extract revealed the isolation and characterization of seven compounds; two new compounds; 1,1',8,8'-tetrahydroxy -3'- acetyl -3-methyl -5,5'bianthracene -9, 9',10,10'-tetraone (2) and 1,6,8-trihydroxy-7-methoxy-3- methyl anthraquinone (3), five known compounds, $\beta$-sitosterol (1), emodin (4), chrysophanol (5), physicon (6) and $\beta$-sitosterol-3-O- $\beta-D$-glucoside (7). This is the first report of the isolation of emodin and $\beta$-sitosterol-3-O- $\beta-D-$-glucoside from genus Aloe and physicon from family Liliaceae. All structures of the isolated compounds were determined using several spectroscopic techniques; UV, IR, MS, NMR $\left({ }^{1} \mathrm{H} N M R\right.$ and ${ }^{13} \mathrm{C}$ NMR) and by comparison with literature data.
\end{abstract}

Keywords: Aloe grandidentata; Anthraquinones; Emodin; Physicon; Anti-inflammatory; Antihyperglycemic; Antimicrobial

\section{Introduction}

Aloe (Liliaceae) is a large genus of 400 species native to Africa, Madagascar, and Arabia [1]. Aloe has a wide range of medicinal application such as laxative effect, wound healing effect, reduces blood sugar in diabetes, soothes burns, eases intestinal problems, reduces arthritic swelling, ulcer curative effect, stimulates immunes response against cancer etc. [2]. Studied pharmacological effects of Aloe as in vitro or in animals include antimicrobial [3], anti-inflammatory and anti-arthritic activity [4,5] and hypoglycemic effects [6-8]. Several constituents were isolated from different Aloe species; sterols, lignin, saponins, anthrones, their dimmers, chromones, flavones, C-gylycosides of anthrone and chromones [9] and glycoproteins and polysaccharides $[9,10]$. Aloe grandidentata is a green fleshy plant reaches up to $30 \mathrm{~cm}$ height, flourishes in Egypt and flowers in January till June; the subterranean part consists of rhizome and adventitious roots [11]. Nothing was found about chemical constituents and biological activity of $A$. grandidentata, so the present study was planned to investigate both chemical constituents and biological effect of the plant.

The protocol of the study was approved by the Research Ethics Committee in the Faculty of Pharmacy, Cairo University, Cairo, Egypt.

\section{Materials and Methods}

General experimental procedures: IR, Schimadzu IR-435, PU9712 infrared spectrophotometer; UV, Schimadzu UV 1650 PC; ${ }^{1} \mathrm{H}-\mathrm{NMR}(300 \mathrm{MHz})$ and ${ }^{13} \mathrm{C}-\mathrm{NMR}(75 \mathrm{MHz})$, Jeol Ex-300 MHZ and Bruker AC - 300 spectrometer; MS, Varian Mat 711, Finnigan mass SSQ 7000 Mass spectrometer, 70 eV; CC, Silica gel 60 (Merck, 230-400 mesh) and Sephadex LH-20 (Sigma); TLC, Pre-coated silica gel plates (Merck, Kieselgel 60 F254, 0.25 mm).

Microorganisms: Bacillus subtilis, Staphylococcus aureus, klebsiellapneumoniae, Escherichia coli, Pseudomonas aeruginosa and Candida albicans were obtained from Microbiology Department, Faculty of Pharmacy, Al Azhar University, Cairo, Egypt were used.

Animals: Adult male albino rats of Sprauge Dawely Strain weighing (100-150 g) were obtained from the animal house colony at the National
Research Center (Dokki, Giza, Egypt) and kept on standard laboratory diet and under hygienic conditions.

Drugs: Carrageenan (Sigma Co., USA), for induction of inflammation; indomethacin (Indomethacin), Egyptian Int. Pharmaceutical Industries Co.; (EIPICO, under license of Merck \& Co. INC-RAHAWY N.J., USA), as standard anti- inflammatory; Alloxan (Sigma Co., USA), for induction of diabetes; metformin (Cidophage) ${ }^{\circ}$, Chemical Industries Development Co. (CID CO.), Giza, Egypt, as antidiabetic; Kits for measuring blood glucose levels Bio-Merieux Co., France; Ciprofloxacin antibiotic (Hoechst), standard antibacterial and Nystatin (Squibb), standard antifungal.

Collection and extraction of plant material: Aloe grandidentata leaf was collected during the summer at flowering stage from EL Orman Garden and the Experimental and Research Station of Faculty of Pharmacy, Cairo University, Giza, Egypt. It was identified and authenticated by Dr. Wafaa Amer, Professor of Plant Taxonomy, Botany Department, Faculty of Science, Cairo University, Cairo, Egypt and a voucher specimen has been deposited in Pharmacognosy Department, College of Pharmacy, Cairo University, Egypt.

The powdered, air dried leaves (570 g) was exhaustively extracted by percolation in $95 \%$ ethanol. The extract was evaporated in vacuo to yield $79 \mathrm{~g}$ of crude alcohol extract (A). Crude alcohol extract was suspended in water and fractionated with petroleum ether, chloroform, ethyl acetate and n-butanol saturated with water. Each fraction was dried over anhydrous sodium sulphate and evaporated to dryness to

*Corresponding author: Taghreed Abdou Ibrahim Shehata, Associate Professor of Pharmacognosy, College of Pharmacy, King Saud University, Saudi Arabia, Tel: 00966556639972; Fax: 00966112062183; E-mail: tshehata@ksu.edu.sa

Received October 27, 2013; Accepted December 18, 2013; Published December 21,2013

Citation: Ibrahim TA, Fiki NME, Shehata IA, Sleem AA, Shoukry MM (2013) Phytochemical and Biological Investigation of Aloe Grandidentata Salm-Dyck. Med chem 4: 298-302. doi:10.4172/2161-0444.1000155

Copyright: (c) 2013 Ibrahim TA, et al. This is an open-access article distributed under the terms of the Creative Commons Attribution License, which permits unrestricted use, distribution, and reproduction in any medium, provided the original author and source are credited. 
yield fraction B (petroleum ether, $18.6 \mathrm{~g}$ ), fraction C (chloroform, 9.1 $\mathrm{g})$, fraction $\mathrm{D}$ (ethyl acetate, $4.3 \mathrm{~g}$ ) and fraction $\mathrm{E}$ (n-butanol $6.1 \mathrm{~g}$ ).

Chromatographic separation of plant fractions: Fraction B (15 g) was applied to flash chromatography using silica gel (200-400 mesh) column, $(50 \mathrm{~cm} \times 5 \mathrm{~cm}, 300 \mathrm{~g})$. The column was eluted using increasing concentrations of $\mathrm{n}$ - hexane, chloroform, ethyl acetate, and methanol through increasing polarity by $10 \%$ to end up with five pooled subfractions. Subfraction II (540 mg, n-hexane: $\mathrm{CHCl}_{3} 8: 2$ ) was subjected to further chromatographic separation on a sephadex LH20 column, eluted with methanol. $\beta$-sitosterol (1) $56 \mathrm{mg}$ was isolated, while further rechromatographic separation afforded 31.4 mg of 1,1',8,8'-tetrahydroxy -3'- acetyl -3-methyl -5,5'bianthracene -9 , 9',10,10'-tetraone (2).

Subfraction III (100 mg, n-hexane: $\left.\mathrm{CHCl}_{3} 4: 6\right)$ was further chromatographed on silica gel column, eluted with n-hexane-ethyl acetate $(7: 3 \mathrm{v} / \mathrm{v})$ to afford $16.7 \mathrm{mg}$ of 1,6,8-trihydroxy-7-methoxy-3methyl anthraquinone (3).

Fraction C (8 g) was subjected to flash chromatography using

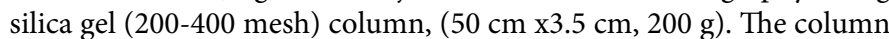
was eluted using $\mathrm{n}$ - hexane, chloroform, ethyl acetate, and methanol through increasing polarity by $5 \%$ to yield three pooled subfractions (I-III). Subfraction I (361 mg, n-hexane: $\mathrm{CHCl}_{3} 8: 2$ ) was subjected to chromatographic separation on a sephadex $\mathrm{LH}_{2} 0$ column, eluting with methanol to afford $39 \mathrm{mg}$ of emodin (4). Subfractions II and III (200 mg, n-hexane: $\mathrm{CHCl}_{3} 6: 4$ and $687 \mathrm{mg}, \mathrm{CHCl}_{3}$ : ethyl acetate 1:1, respectively) were separately, subjected to repeated chromatographic separation on a sephadex LH20 column, to yield $10.8 \mathrm{mg}$ of chrysophanol (5) and $60.2 \mathrm{mg}$ of physicon(6), from subfractions II and III, respectively.

Fraction D (4 g) was similarly, subjected to silica gel column chromatography, subfraction $42\left(187 \mathrm{mg}\right.$, ethyl acetate: $\mathrm{CH}_{3} \mathrm{OH}$ 9:1) was rechromatographed on LH20 column to afford $15 \mathrm{mg}$ of $\beta$-sitosterol-3-O- $\beta$-D-glucoside (7).

Compounds 1, 4-7 were detected through comparison of TLC behavior with authentic standard, melting point and mixed melting point. In addition to comparing their spectroscopic data with that reported in literatures. In addition, compounds 2,3 were investigated through their spectroscopic data.

\section{1,1',8,8'-tetrahydroxy-3'-acetyl-3-methyl -5,5' bianthracene-9, 9',10,10'-tetraone (compound 2)}

MP: $190-192^{\circ} \mathrm{C}$.

$\mathrm{R}_{\mathrm{f}}: 0.47$ (n-Hexane-EtOAc, 8:2).

IR (KBr): 3563, 3436, 2923, 2851, 1671, 1624, 1452, $1428,1374,1270,1202 \mathrm{~cm}^{-1}$.

UV/Vis $\lambda_{\text {max }}(\mathrm{MeOH}) \mathrm{nm}: 206,222,260,390,440$.

${ }^{1} \mathrm{H}$ NMR (300 MHz, $\left.\mathrm{CDCl}_{3}\right): 11.92,11.94,12.03$ and $12.49(1 \mathrm{H}, \mathrm{s}$, H-1', H-1, H-8' and H-8), 7.04, 7.19, 7.52, and $7.63(1 \mathrm{H}, \mathrm{s}, \mathrm{H}-2, \mathrm{H}-2$ ', $\mathrm{H}-4^{\prime}$ and $\left.\mathrm{H}-4\right), 7.21\left(\mathrm{~d}, \mathrm{~J}=8.7 \mathrm{~Hz}, \mathrm{H}-7^{\prime}\right) ; \delta 7.31(\mathrm{~d}, \mathrm{~J}=7.8 \mathrm{~Hz}, \mathrm{H}-7) ; \delta$ $7.51\left(\mathrm{~d}, \mathrm{~J}=8.7 \mathrm{~Hz}, \mathrm{H}-6^{\prime}\right)$ and $\delta 7.88(\mathrm{~d}, \mathrm{~J}=7.8 \mathrm{~Hz}, \mathrm{H}-6), 2.42(3 \mathrm{H}, \mathrm{s}$, H-3), 2.07 (3H, s, H-3').

${ }^{13} \mathrm{C}$ NMR $\left(75 \mathrm{MHz} \mathrm{CDCl}_{3}\right): 162.87\left(\mathrm{C}-8^{\prime}\right), 162.74(\mathrm{C}-8) 162.03$ (C-1), 159.64 (C-1'),149.37 (C-3), 149.15 (C-3'), 137.10(C-4a), 135.95 (C -4'a),134.01(C -6), 133.53 (C-6'), 130.82 (C-5'), 128.77(C-5), 125.83 (C-10a), 125.05 (C-10'a), 124.27 (C-2), 124.10 (C -2'), 121.66 (C-4), 121.32 (C- 4'), 120.31 (C-9'a), 119.98 (C- 9a), 115.72(C-7), 115.46(C$\left.7^{\prime}\right), 114.80(\mathrm{C}-8 \mathrm{a})$ and $113.91\left(\mathrm{C}-8^{\prime} \mathrm{a}\right)$.
MS (EI, $70 \mathrm{eV}): \mathrm{m} / \mathrm{z}(\%)=507\left[\mathrm{M}-\mathrm{CO}-\mathrm{CH}_{3}\right]^{+}(8), 506\left[\mathrm{M}-\mathrm{CO}-\mathrm{CH}_{3}\right.$ $-1]^{+}(29), 489\left[\mathrm{M}-\mathrm{CO}-\mathrm{CH}_{3}-\mathrm{H}_{2} \mathrm{O}\right]^{+}(13), 253[\mathrm{M} / 2]^{+}(11)$.

\section{1,6,8-trihydroxy-7-methoxy-3- methyl anthraquinone (compound 3)}

MP: $236-238^{\circ} \mathrm{C}$.

$\mathrm{R}_{\mathrm{f}}: 0.8\left(\mathrm{CHCl}_{3}-\mathrm{MeOH}, 9.5: 0.5\right)$.

IR (KBr): 3418, 2920, 2838, 1720, 1622, 1516, 1454, 1265, 1201, $1161,1032 \mathrm{~cm}^{-1}$.

$\mathrm{UV} / \mathrm{Vis} \lambda_{\text {max }}(\mathrm{MeOH}) \mathrm{nm}: 233,250,302,312,458$.

${ }^{1} \mathrm{H}$ NMR $\left(300 \mathrm{MHz}, \mathrm{CDCl}_{3}\right): 12.3,12.5(1 \mathrm{H}, \mathrm{s}, \mathrm{OH}$ at $\mathrm{H}-1$ and $\mathrm{H}-8)$, 2.51(3H,s Me-3), 4.45 ( $1 \mathrm{H}$, brs, $\mathrm{OH}$ at $\mathrm{H}-6), 3.80\left(3 \mathrm{H}, \mathrm{s}, \mathrm{OCH}_{3}\right.$ at $\left.\mathrm{H}-7\right)$, 6.83(1H, s, H-2), 7.72(1H, d, J = 3, H-4), $7.42(1 \mathrm{H}, \mathrm{s} \mathrm{H}-5)$.

${ }^{13} \mathrm{C}$ NMR (75 MHz DMSO-d $)$ : 22.29 (Me, C-3), $68.17\left(\mathrm{OCH}_{3}, \mathrm{C}-7\right)$ and $159.92(\mathrm{OH}, \mathrm{C}-6), 120.01$ (C-8a), 121.35 (C-9a), $124.14(\mathrm{C}-4)$ 125.53 (C-2), 128.78 (C-10a), 130.84 (C-5), 137.14 (C-4a), 149.18 (C3), 162.06 (C-1), 162.90 (C-8), 180.06 (C-10), 192.88 (C-9).

MS (EI, $70 \mathrm{eV}): \mathrm{m} / \mathrm{z}(\%)=300\left[\mathrm{M}^{+}\right](96), 285\left[\mathrm{M}^{+}-\mathrm{CH}_{3}\right](38), 271$ $\left[\mathrm{M}^{+}-\mathrm{CHO}\right](46), 257\left[\mathrm{M}^{+}-\mathrm{CO}-\mathrm{CH}_{3}\right](100)$.

Antimicrobial activity: The antimicrobial activity was tested using agar disc diffusion method [12]. A suspension of the tested microorganism $(0.1 \mathrm{~mL}$ of 108 cells per $\mathrm{mL}$ ) was spread on solid media plates. Aliquots of $15 \mu \mathrm{g}$ of the alcohol extract (fraction A) dissolved in dimethyl sulfoxide (DMSO, Merck, Germany) were applied on sterile paper discs (6 $\mathrm{mm}$ diameter). Ciprofloxacin and nystatin were used as standard antibacterial and antifungal agents, respectively, as positive controls, and DMSO without the extracts was used as a negative control. The discs were deposited on the surface of inoculated agar plates. These plates were held at $4^{\circ} \mathrm{C}$ for $2 \mathrm{~h}$, followed by incubation at $37^{\circ} \mathrm{C}$ for $24 \mathrm{~h}$ for bacteria, or at $30^{\circ} \mathrm{C}$ for $48 \mathrm{~h}$ for yeasts. The diameters of the inhibitory zones were measured in millimeters. All tests were performed in triplicate.

Anti-inflammatory activity: This effect was determined according to the method described by Winter et al. [13]. Eighteen male albino rats, weighing (130-150g) were randomly divided into three groups, each of six animals, first group; received $1 \mathrm{ml}$ of saline serving as control, second group; received $100 \mathrm{mg} / \mathrm{kg}$ b. wt. of the ethanol extract (A), third group; received $20 \mathrm{mg} / \mathrm{kg} \mathrm{b}$. wt. of the reference drug Indomethacin. One hour later after drug administration, all the animals received a sub plantar injection of $0.1 \mathrm{ml}$ of $1 \%$ carrageenan solution in saline in the right hind paw and $0.1 \mathrm{ml}$ saline in the left hind paw. Four hours after drug administration, the rats were sacrificed; both hind paws excised and weighed separately. The percentage of oedema (inflammation) was calculated according to the following equation:

$$
\mathrm{X} 100 \% \text { Oedema }=\frac{\text { Weight of right paw }- \text { Weight of left paw }}{\text { Weight of left paw }} \times 100
$$

Antihyperglycemic activity: The alcohol extract of $A$. grandidentata was tested for its anti-hyperglycemic activity over long period ( 2 months). The blood glucose level was monitored after 4 and 8 weeks from zero time. Thirty male albino rats of the Sprague Dawely strain $(130-140 \mathrm{~g})$ were injected intraperitoneal with alloxan $(150 \mathrm{mg} /$ $\mathrm{kg}$ body weight) to induce diabetes mellitus [14]. Animals were divided into 3 groups; Hyperglycemia was assessed after 72 hours by measuring blood glucose [15] and after 1 and 2 months intervals from treatment. First group; diabetic rats that served as positive control, second groups; 
diabetic rats that received $100 \mathrm{mg} / \mathrm{kg} \mathrm{b}$. wt. of the ethanol extract (A), third group; diabetic rats that received $150 \mathrm{mg} / \mathrm{kg}$ b. wt. of Metformin as reference standard drug. At the end of each study period, blood samples were collected from the retro orbital venous plexus through the eye canthus of anaesthetized rats after an overnight fast. Serum was isolated by centrifugation and the blood glucose level was measured [15]. Blood glucose level was measured at zero $G_{0}$ and after treatment $\mathrm{G}_{\mathrm{t}}$. Percentage of change in blood glucose level was calculated from the following equation:

$$
\% \text { of change }=\left(\mathrm{G}_{0}-\mathrm{G}_{\mathrm{t}} / \mathrm{G}_{0}\right) \times 100
$$

At the end of the experiments, all dead animals were getting rid by frozen till incineration.

\section{Results}

The structure (Figure 1A) of the known compounds; $\beta$-sitosterol( 1 ) and $\beta$-sitosterol-3-O- $\beta$-D-glucoside (7) [16], emodin (4), chrysophanol (5) and physicon $(6)[17,18]$ were determined by comparison of their physical and spectroscopic data (UV, ${ }^{1} \mathrm{H}$ NMR, ${ }^{13} \mathrm{C}$ NMR and MS) with those reported in literature. Physicon (6) is isolated for the first time in family Liliaceae. Meanwhile, Emodin (4) and $\beta$-sitosterol-3-O$\beta$-D-glucoside (7) are isolated for the first time from the genus Aloe. $\beta$-sitosterol (1) and Chrysophanol (5) were previously reported from other Aloe species [19] but they are isolated for the first time from the leaves of A. grandidentata.

The structure (Figure 1B) of the new compounds; 1,1',8,8'-tetrahydroxy -3 - acetyl -3 -methyl $-5,5$ bianthracene -9 , 9',10,10'tetraone (2) and 1,6,8-trihydroxy-7-methoxy-3- methyl anthraquinone (3) were determined by their physical and chemical characters and spectroscopic data (UV, ${ }^{1} \mathrm{H}$ NMR, ${ }^{13} \mathrm{C}$ NMR and MS).

Compound 2 (Figure 1B) was obtained as orange crystals soluble in $\mathrm{CHCl}_{3}$, gave positive tests for anthraquinones. A molecular formula of $\mathrm{C}_{31} \mathrm{H}_{18} \mathrm{O}_{10}$ was determined for compound 2 on the basis of molecular ion peak at $\mathrm{m} / \mathrm{z} 507\left(\mathrm{M}-\mathrm{CO}-\mathrm{CH}_{3}\right)$. The ${ }^{1} \mathrm{HNMR}$ spectra showed four hydrogen bonded phenol proton signals appeared at $\delta 11.92,11.94$, 12.03 and 12.49. It also revealed signals for four aromatic protons resonating with o-coupling at $\delta 7.21\left(\mathrm{~d}, \mathrm{~J}=8.7, \mathrm{H}-7^{\prime}\right) ; \delta 7.31(\mathrm{~d}, \mathrm{~J}=7.8$, $\mathrm{H}-7) ; \delta 7.51(\mathrm{~d}, \mathrm{~J}=8.7, \mathrm{H}-6 \mathrm{\prime})$ and $\delta 7.88(\mathrm{~d}, \mathrm{~J}=7.8, \mathrm{H}-6)$ and four singlets at $7.04,7.19,7.52$ and $7.63(1 \mathrm{H}, \mathrm{s}, \mathrm{H}-2, \mathrm{H}-2, \mathrm{H}-4$ and $\mathrm{H}-4)$. A singlet of three protons appeared at $\delta 2.42$ designated for methyl group at position 3 and also another one at $\delta 2.07$ for an acetyl group at position $3 '$. The location of the biaryl bond followed from the absence of signal arising from $\mathrm{H}-5$ and $\mathrm{H}-5^{\prime}$ [20]. ${ }^{13} \mathrm{C}-\mathrm{NMR}$ spectrum revealed 31 signals that could be assigned to individual Carbon atoms on the following basis; the carbonyl carbons C-9, C-9', C-10' and C-10 resonated at $\delta$ $192.82,192.31,182.29$ and $181.84 \mathrm{ppm}$ respectively. The acetyl carbon resonated at $\delta 167.70$ for the carbonyl $\mathrm{C}\left[\mathrm{OCO} \mathrm{CH}_{3}\right]$ and at $\delta 21.38$ for the methyl $\mathrm{C}\left[\mathrm{OCO} \mathrm{CH}_{3}\right]$. The methyl group was found at $\delta 22.27 \mathrm{ppm}$. These data coincided with ${ }^{1} \mathrm{H}-\mathrm{NMR}$ data.

In addition the $\lambda_{\text {max }}^{\mathrm{MeOH}}$ at 260, 390 and $440 \mathrm{~nm}$ besides the high molecular weight supported that compound 2 was a new polyhydroxybianthraquinoid isolated for the first time. On the basis of the available spectral evidences the structure was established to be 1,1',8,8'-tetrahydroxy-3'-acetyl -3- methyl -5, 5-bianthracene $-9,9^{\prime}, 10,10^{\prime}$-tetraone.

Compound 3 (Figure 1B) was obtained as orange crystals with m.p. $236-238^{\circ} \mathrm{C}$, soluble in chloroform and gives positive tests for anthraquinone. A molecular formula of $\mathrm{C}_{16} \mathrm{H}_{12} \mathrm{O}_{6}$ was determined for compound 3 on the basis of the observed molecular ion peak at $\mathrm{m} / \mathrm{z}$ 300. The ${ }^{1} \mathrm{H}-\mathrm{NMR}$ spectra of compound 3 displayed a signal for $\mathrm{CH}_{3}$ appeared at $2.51\left(3 \mathrm{H}, \mathrm{s}, \mathrm{CH}_{3}-3\right)$, the hydroxyl group appeared at $4.45(1 \mathrm{H}$, brs, $\mathrm{H}-6)$ this elucidation is comparable to that of emodin but it differs by the presence of a sharp signal appeared at $3.80(3 \mathrm{H}, \mathrm{s})$ denoting the presence of methoxy $\left(\mathrm{OCH}_{3}\right)$ group typical for aromatic methoxy group at position 7 . Those signals were beside the aromatic proton signal which appeared at $6.83(1 \mathrm{H}, \mathrm{s}, \mathrm{H}-2)$. The meta coupling protons is confirmed by the presence of a signal at $7.72(1 \mathrm{H}, \mathrm{d}, \mathrm{J}=3$, $\mathrm{H}-4)$ and a signal at $\delta 7.42(1 \mathrm{H}, \mathrm{s}, \mathrm{H}-5)$. In addition to a characteristic methoxy group signal at $\delta 68.17$ and methyl at 22.29 , the ${ }^{13} \mathrm{C} N M R$ spectra of compound 3 displayed 14 carbon signals. The chemical shifts of these 14 resonance signals suggested the presence of two aromatic rings and two doubly conjugated carbons $\left(\delta_{c} 180.06,192.88\right)$. Accordingly, the structure of this new compound (3) was determined as 1,6,8-trihydroxy-7-methoxy-3-methylanthraquinone.

The results of antimicrobial activity of the alcoholic extract of A. grandidentata $(200 \mathrm{mg} / \mathrm{ml})$ are shown in Table 1 . It showed mild antibacterial activities against $G$ +ve bacteria, $G$-ve bacteria and fungi with the strongest effect being detected against Pseudomonas aeruginosa. These results were in agreement with observations previously reported for several Aloe species [3]. The antimicrobial activities of the alcoholic extract of $A$. grandidentata might be attributed to its contents of anthraquinones [21] or $\beta$-sitosterol [22].

The results of experiments examining the effects of the alcoholic extract of $A$. grandidentata leaf on carrageenan-induced paw edema are presented in Table 2 .

The assay revealed that oral administration of $100 \mathrm{mg} / \mathrm{kg} \mathrm{b}$. wt. alcoholic extract reduced paw edema by $59.7 \%$. The results showed

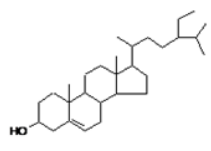

[1]
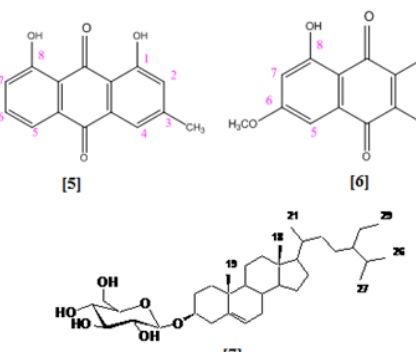

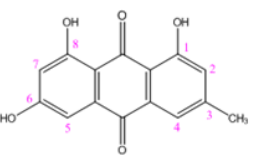

[4]

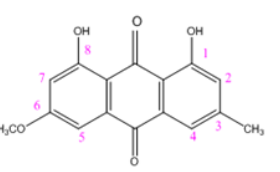

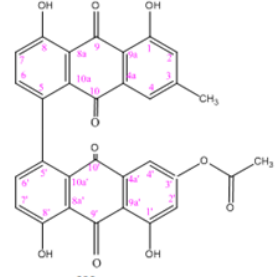

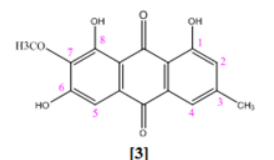

Figure 1: A: Structure of known compounds isolated from the leaf of $A$ grandidentata. B: Structure of new compounds isolated from the leaf of $A$ grandidentata.

\begin{tabular}{|l|l|l|l|}
\hline \multicolumn{4}{|l|}{ Diameter of inhibition zone \pm SE $(\mathrm{mm})$} \\
\hline Micro- organisms & $\begin{array}{l}\text { Alcohol extract of } A . \\
\text { grandidentata(200 } \mathrm{mg} / \mathrm{ml})\end{array}$ & Ciprofloxacin & Nystatin \\
\hline Staphylococcus aureus & $\mathrm{R}$ & $22 \pm 0.44$ & N.D \\
\hline Bacillus subtilis & $9 \pm 0.53$ & $22 \pm 0.95$ & N.D \\
\hline Pseudomonas & $\mathrm{R}$ & $35 \pm 0.78$ & N.D \\
\hline aeruginosa & $11 \pm 0.74$ & $34 \pm 0.83$ & N.D \\
\hline klebsiellapnemonia & $9 \pm 0.37$ & $19 \pm 0.52$ & N.D \\
\hline Candida albicans & $8 \pm 0.27$ & N.D & $16 \pm 0.62$ \\
\hline
\end{tabular}

$\mathrm{R}=$ no inhibition zone $\quad \mathrm{N} . \mathrm{D}=$ not done $\quad \mathrm{SE}$ standard error

Table 1: Results of antimicrobial screening of alcohol extract of $A$. gradidentata. 
Citation: Ibrahim TA, Fiki NME, Shehata IA, Sleem AA, Shoukry MM (2013) Phytochemical and Biological Investigation of Aloe Grandidentata SalmDyck. Med chem 4: 298-302. doi:10.4172/2161-0444.1000155

\begin{tabular}{|c|c|c|c|}
\hline \multirow[t]{2}{*}{ Group } & \multicolumn{3}{|c|}{$\%$ oedema } \\
\hline & Mean \pm S.E. & $\%$ of change & $\%$ of Potency \\
\hline Control (1 ml saline) & $61.8 \pm 1.3$ & - & - \\
\hline Alcohol extract (100 mg/kg b. wt.) & $24.9 \pm 1.1^{*}$ & 59.7 & 92.01 \\
\hline Indomethacin (20 mg/kg b. wt.) & $21.7 \pm 0.9^{*}$ & 64.88 & 100 \\
\hline
\end{tabular}

Potency calculated as compared to the standard anti- inflammatory drug Indomethacin

* Significantly different from control group at $p<0.01$

$\%$ of change is calculated as regard to the control group. S.E.=standard error

Table 2: Results of acute anti-inflammatory effect of the alcohol extract of $A$. grandidentataSalm. - Dyck, in male albino rats ( $n=6$ ).

\begin{tabular}{|c|c|c|c|c|c|c|c|}
\hline & \multicolumn{3}{|c|}{ Zero } & \multicolumn{2}{|c|}{4 weeks } & \multicolumn{2}{|l|}{8 weeks } \\
\hline Group & Mean \pm S.E & Mean \pm S.E & $\%$ of change & $\%$ of potency & Mean \pm S.E & $\%$ of change & $\%$ of potency \\
\hline -ve control & $261.2 \pm 9.8$ & $263.4 \pm 10.3$ & - & - & $265.7 \pm 11.9$ & - & - \\
\hline Alcohol extract (100 mg/kg b. wt.) & $256.9 \pm 10.5$ & $141.2 \pm 6.7^{*}$ & 45.03 & 95.26 & $112.4 \pm 5.1^{*}$ & 56.24 & 86.83 \\
\hline Metformin (150 mg/kg b. wt.) & $258.9 \pm 8.4$ & $136.5 \pm 6.1^{*}$ & 47.27 & 100 & $91.2 \pm 4.6^{*}$ & 64.77 & 100 \\
\hline
\end{tabular}

${ }^{*} \mathrm{P}<0.01$ vs control group or statistically significant difference from zero time at $\mathrm{p}<0.01$

$\%$ of change calculated as regard the control group. S.E.=standard error

Table 3: Effect of alcohol extract of $A$. grandidentata Salm.-Dyckon diabetic male albino rats $(n=10)$.

that the alcoholic exerted $92.01 \%$ potency as that standard antiinflammatory drug indomethacin. These results were in agreement with findings previously reported for several Aloe species $[4,5,13]$.

This activity might be due to the presence of anthraquinones $[23,24]$ $\beta$-sitosterol $[25,26]$ and $\beta$-sitosterol3-O- $\beta$-D-glucoside[26] which have been reported to possess anti-inflammatory activities.

The observed data (Table 3) revealed that A. grandidentata Salm. Dyck at dose $100 \mathrm{mg} / \mathrm{kg}$, reduced the blood glucose level by (45.03\%) and $(56.24 \%)$ after treatment for 4 weeks and 8 weeks respectively. This study represented the first report; for A. grandidentata Salm. - Dyck to have a potent antidiabetic effect equivalent to $95.26 \%$ and $86.83 \%$ after 4 weeks and 8 weeks respectively comparing to the standard antidiabetic drug Metformin. These results were in agreement with findings previously reported for Aloe vera [6-8].

The hypoglycemic effect of alcoholic extract of A. grandidentata may be attributed to its content of chrysophanol [27].

\section{Acknowledgement}

The authors wish to deeply thank Dr. Sayed A. El Toumy, Professor of Pharmacognosy, National Research Center, Giza, Egypt for his help in interpretation of the spectral data.

\section{References}

1. Adams SP, Leitch IJ, Bennett MD, Chase MW, Leitch AR (2000) Ribosomal DNA evolution and phylogeny in Aloe (Asphodelaceae). Am J Bot 87: 15781583.

2. Adibe MO, Ukwe CV, Ekwunife OI (2009) Evaluation of therapeutic uses of Aloe barbadensis Miller (Aloe vera) plant among staff and students in a Nigerian university. Int.J.Ph.Sci1: 59-70.

3. Agarry OO, Olaleye MT, Bello-Michael CO (2005) Comparative antimicrobial activities of Aloe veragel and leaf. African Journal of Biotechnology 4: 14131414.

4. Egesie UG, Chima KE, Galam NZ (2011) Anti-inflammatory and analgesic effects of aqueous extract of Aloe vera (Aloe barbadensis) in rats. African Journal of Biomedical Research 14: 209- 212.

5. Davis RH, Maro NP (1989) Aloe vera and gibberellin. Anti-inflammatory activity in diabetes. J Am Podiatr Med Assoc 79: 24-26.

6. Anupama G, Jyoti S, Sushma S, Kiran D, Gajynder S, et al (2011) Evaluation of hypoglycemic and anti atherogenic effect of Aloe verain diabetes mellitus. PharmacieGlobale2:1-4.

7. Tanaka M, Misawa E, Ito Y, Habara N, Nomaguchi K, et al.(2006) Identification of five phytosterols from Aloe vera gel as anti-diabetic compounds. Biol Pharm Bull 29: 1418-1422.

8. Saghir AJ, Syed SH, Aftab N, Kalsoom, Javedl (2011) Hypoglycemic effect of
Aloe vera extract in alloxan induced diabetic albino rats. Medical Journal of Islamic World Academy of Sciences 19: 127-130.

9. Evans WC(2002) Trease and Evanspharmacognosy (15 th edition). Edinburgh, WB Saunders, pp: 241-242.

10. Braun L, Cohen M (2005) Herbs and natural supplements: an evidence-based guide,Elsevier, Sydney, pp: 62-64.

11. Mouchira AC (2011) Pharmacognostical and biological study of certain Aloe species cultivated in Egypt. PhD thesis, Faculty of Pharmacy, Cairo University, Egypt.

12. Bauer AW, Kirby WMM, Sheriss JC, Turck M (1996) Antibiotic susceptibility testing by standardized single disk method. Am J ClinPathol 45: 493-496.

13. Winter GA, Risley EA, Nuss GW (1962) Carrageenin-induced edema in hind paw of the rat as an assay for antiflammatory drugs. ProcSocExpBiol Med 111: 544-547.

14. Eliasson SG, Samet JM (1969) Alloxan induced neuropathies: lipid changes in nerve and root fragments. Life Sci8: 493-498.

15. Trainder $P$ (1969) Determination of blood glucose using an oxidase-peroxidase system with a non-carcinogenic chromogen.J ClinPathol22: 158-161.

16. Good JL, Akisha T (1997) Analysis of sterols (1st edn), Blackie Academic and Professional Press, Champan and Hall London.

17. Berger S, Ricker A (1974) Identification and determination of quinines In The chemistry of quinonoid compounds. Part I, (S. Patai ed.), London, New York, Sydney, Toronto, J. Wiley and Sons.

18. Thomson RH (1971) Naturally occurring quinonea $\left(2^{\text {nd }} e d n\right)$ Academic Press Inc, London and New York

19. Blitzke T, Masaoud M, Schmidt J (2001) Constituents of Aloe rubroviolacea Fitoterapia72: 78-79.

20. Wirz A, Simmen U, Heilmann J, Calis I, Meier B, et al. (2000)Bisanthraquinone glycosides of Hypericumperforatum with binding inhibition to $\mathrm{CRH}-1$ receptors. Phytochemistry 55:941-947.

21. Ali AM, Ismail NH, Mackeen MM, Yazan LS, Mohamed SM, et al. (2000) Antiviral, cyototoxic and antimicrobial activities of anthraquinones isolated from the roots of Morindaelliptica. Pharm Biol 38: 298-301.

22. Amit S, Poonam D, Kshitiz K, Sanjay S, TejovathiG(2012)Analysis of IR, NMR and Antimicrobial Activity of $\beta$-Sitosterol Isolated from Momordicacharantia. Science Secure Journal of Biotechnology 1: 9-13.

23. Choi RJ, Ngoc TM, Bae K, Cho HJ, Kim DD, et al. (2013) Anti-inflammatory properties of anthraquinones and their relationship with the regulation of P-glycoprotein function and expression. Eur J Pharm Sci 48: 272-281.

24. Chen RF, Shen YC, Huang HS, Liao JF, Ho LK, et al. (2004) Evaluation of the anti-inflammatory and cytotoxic effects of anthraquinones and anthracenes derivatives in human leucocytes. J Pharm Pharmacol 56: 915-919.

25. Nirmal SA, Pal SC, Mandal SC, Patil AN(2012) Analgesic and antiinflammatory activity of $\beta$-sitosterol isolated from Nyctanthesarbortristis leaves. Inflammopharmacology 20: 219-224. 
Citation: Ibrahim TA, Fiki NME, Shehata IA, Sleem AA, Shoukry MM (2013) Phytochemical and Biological Investigation of Aloe Grandidentata SalmDyck. Med chem 4: 298-302. doi:10.4172/2161-0444.1000155

26. Choi JN, Choi YH, Lee JM, Noh IC, Park JW, et al. (2012) Anti-inflammatory effects of $\beta$-sitosterol- $\beta$-D-glucoside from Trachelospermumjasminoides(Apoc ynaceae) in lipopolysaccharide-stimulated RAW 264.7 murine macrophages. Nat Prod Res 26: 2340-2343.
27. Lee MS, Sohn CB(2008) Anti-diabetic properties of chrysophanol and its glucoside from rhubarb rhizome. Biol Pharm Bull 31: 2154-2157. 